\title{
The effect of endotoxin on functional parameters of mammary CID-9 cells
}

\author{
B Safieh-Garabedian, G M Mouneimne, W El-Jouni, M Khattar and R Talhouk \\ Department of Biology, Faculty of Arts and Sciences, PO Box 11-0236 American University of Beirut, Beirut, \\ Lebanon \\ Correspondence should be addressed to R Talhouk; Email: rtalhouk@aub.edu.lb
}

G M Mouneimne is currently at Department of Anatomy and Structural Biology, Albert Einstein College of Medicine, New York, New York 10461, USA

\begin{abstract}
The effect of endotoxin on mammary CID-9 cells, which differentiate in culture and express $\beta$-casein, was investigated. Cells in culture supplemented with lactogenic hormones and dripped with EMS-Matrix (EMS-drip), were treated daily with endotoxin $(0.5-500 \mu \mathrm{g} / \mathrm{ml})$. Endotoxin at concentrations of less or equal to $10 \mu \mathrm{g} / \mathrm{ml}$ did not affect cell growth and viability up to 5 days post endotoxin treatment. Endotoxin $(0.01-10 \mu \mathrm{g} / \mathrm{ml})$ was added to the culture medium, upon confluence, and functional parameters were examined within $48 \mathrm{~h}$ post endotoxin treatment. Nuclear factor- $\kappa B$ (NF- $\kappa B$ ) (p52) increased in nuclear extracts from endotoxin-stimulated cells within $1 \mathrm{~h}$ of treatment, while $\beta$-casein mRNA and protein expression decreased in a concentration-dependent manner at 24 and $48 \mathrm{~h}$ post treatment. Zymography showed that the 72 and $92 \mathrm{kDa}$ gelatinase activity increased in cells at 24 and $48 \mathrm{~h}$ post endotoxin treatment at 10 and $50 \mu \mathrm{g} / \mathrm{ml}$. At the latter concentration, the active form of $72 \mathrm{kDa}$ gelatinase was induced at $48 \mathrm{~h}$. Interleukin- 6 and tumor necrosis factor- $\alpha$ levels increased at $1-3 \mathrm{~h}$ post endotoxin treatment and peaked at $6 \mathrm{~h}$ in cells on plastic and EHS-drip. Nerve growth factor (NGF) levels increased in control and endotoxin-treated cells in a time-dependent manner, and endotoxin increased NGF levels in culture at 6 and $9 \mathrm{~h}$ post endotoxin treatment. This study shows that endotoxin activated NF-KB, suppressed $\beta$-casein expression and upregulated gelatinases, cytokines and NGF. This model could be used to investigate the role of mammary cells in initiating and propagating inflammation and to test candidate molecules for potential anti-inflammatory properties.

Reproduction (2004) 127 397-406
\end{abstract}

\section{Introduction}

Mastitis, inflammation of the mammary gland, is common in lactating dairy cows and causes major problems for the dairy industry throughout the world, where it affects milk production and causes substantial economical losses (Riollet et al. 2000, Waller 2000). In humans, mastitis manifests itself by symptoms such as breast tenderness, redness and heat, in addition to an increase in heart rate and temperature, and approximately $20-33 \%$ of women who breast-feed are diagnosed as having mastitis (Inch \& Fisher 1995, Semba \& Neville 1999). The impact of the above at both the medical and the economic level cannot be overlooked. Efforts to decipher the mechanism of this inflammation must address the role that both immune cells, recruited to the gland in response to inflammation, and mammary parenchymal cells play in this process.

Several studies have addressed the role of cytokines (Jackson et al. 1990, Shuster et al. 1993, 1997, Homaidan et al. 1995, 1999), matrix metalloproteinases (MMPs) (Talhouk et al. 2000a), and cell-cell interaction (Von Andian et al. 1991, Martin et al. 1998a,b) in cell and/or tissue function during inflammation (Oliver \& Smith 1982, Lengemann \& Pitzrick 1987, Colditz et al. 1990). Moreover, the role of immune cells in inflammation has been extensively studied, but few studies have addressed the role that non-immune parenchymal cells play in mediating inflammatory reactions, especially in the mammary tissue (Okada et al. 1997, 1999, Boudjellab et al. 1998). In brief, these studies demonstrate the production of cytokines by mammary parenchymal cells in vitro and that endotoxin (ET) stimulates the synthesis and secretion of cytokines such as interleukin (IL)-6, IL-1, IL-8 and tumor necrosis factor (TNF)- $\alpha$, suggesting that these cytokines may be involved in resolving mammary bacterial infections. The effect of ET on functional parameters of mammary cells such as production of $\beta$-casein and extracellular matrix (ECM) remodeling proteinases was not addressed. 
ET-induced inflammation affects many cell types, such as lymphocytes, macrophages, epithelial and endothelial cells. One of the initial ET-induced signals is the activation of the transcription factor nuclear factor- $\kappa \mathrm{B}(\mathrm{NF}-\kappa \mathrm{B})$, which in turn activates several other genes that are major players in the inflammatory process, such as nerve growth factor (NGF), cytokines including IL-1 $\beta$, TNF, IL-6, IL-8 and ECM-degrading proteases (Lee et al. 1993, Read et al. 1993, Boudjellab et al. 1998, Bondeson et al. 1999, Kim \& Koh 2000, Tomita et al. 2000, Baldwin 2001, Tak \& Firestein 2001). In addition, some studies have shown that gelatinases are able to regulate the secretion of cytokines, mainly TNF- $\alpha$ and IL-1 $\beta$, and vice versa (Gearing et al. 1994, Zhang et al. 1998).

The aim of this study was to determine the effect of ET on functional parameters of mammary gland non-immune cells and elucidate the role these cells play in the initiation and propagation of the inflammatory process during mastitis. To this effect, we used CID-9 cells, a heterogeneous population of cells, consisting of fibroblasts, epithelial and myoepithelial cells. The CID-9 cells differentiate in culture and express $\beta$-casein in response to ECM, cell-cell interaction and prolactin (Schimdhauser et al. 1990, El-Sabban et al. 2003). Briefly, we demonstrate that ET activates NF-кB, downregulates casein expression, and increases gelatinase and cytokine expression. Moreover, we suggest that this is a suitable in vitro model to study the role of non-immune cells in mammary gland inflammation and for investigating the effect of several anti-inflammatory agents on mammary cell function, during mastitis.

\section{Materials and Methods}

\section{Materials}

Highest grade materials were used. BSA, Coomasie blue R-250, insulin, ovine hydrocortisone, ovine prolactin and trypsin-EDTA, were obtained from Sigma Chemical Co. (St Louis, MO, USA). Escherichia coli, strain 055:B5, lipopolysaccharide, previously used to induce mastitis in lactating dairy cows (Shuster et al. 1993) was purchased from Difco Laboratories (Detroit, MI, USA). Complete Protease Inhibitors, poly(dl-dC), and polynucleotide kinase, were purchased from Boehringer, Mannheim, Germany. Hybond-N membrane, Rediprime kit, and $\left[\alpha-{ }^{32} \mathrm{P}\right] \mathrm{dCTP}$ were from Amersham Pharmacia Biotech. Immobilin-P membranes were from Millipore Continental Water Systems (Bedford, MA, USA). Enhanced chemiluminescence $(E C L)$, horseradish peroxidase-conjugated anti-rabbit IgG and specific antibodies for NF-кB (polyclonal rabbit p50, p52 or p60, anti-NF-кB IgG) were from Santa Cruz Biotechnology (Santa Cruz, CA, USA). Cell culture media and reagents were purchased from Gibco BRL Life Technologies (Gaithersburg, MD, USA). Bio-Rad protein assay was from Bio-Rad (Hercules, CA, USA). EHS-Matrix, growth-factor-reduced Matrigel, was purchased from
Collaborative Biomedical Products (Two Oak Park, Bedford, MA, USA). CID-9 mammary cell strain, polyclonal rabbit anti-mouse milk antiserum, and $\beta$-casein c-DNA inserts were provided by Dr Mina Bissell, Lawrence Berkeley National Laboratory, Berkeley, CA, USA.

\section{CID-9 cell cultures}

Low passage numbers $(17-21)$ of the CID-9 mouse mammary cell strain were used throughout. For maintenance and propagation, cells were grown in 'growth medium' consisting of Dulbecco's Modified Eagle's Medium Nutrient Mixture/F12 Ham (DMEM/F12) with $5 \%$ fetal bovine serum (FBS), insulin $(5 \mu \mathrm{g} / \mathrm{ml})$ and gentamicin $(50 \mu \mathrm{g} / \mathrm{ml})$ in a humidified incubator $(95 \%$ air $\left.5 \% \mathrm{CO}_{2}\right)$ at $37^{\circ} \mathrm{C}$.

Depending on the experimental setup, as indicated for each experiment, CID-9 cells were seeded after trypsinization at $3.0 \times 10^{6}$ cells $/ 75 \mathrm{~cm}^{2}$ culture dish, alternatively at $5.0 \times 10^{6}$ cells $/ 75 \mathrm{~cm}^{2}$ culture dish, with diluted reconstituted basement membrane, growth-factor-reduced, Matrigel $(1.5 \% \mathrm{v} / \mathrm{v})$, in Hanks' balanced salt solution (HBSS) that was dripped (referred to here as EHS-drip) onto cells $24 \mathrm{~h}$ after plating (El-Sabban et al. 2003). Cells cultured on plastic or EHS-drip were first plated in growth medium for initial cell attachment and spreading. Twenty-four hours after plating, cells were washed three times with HBSS and growth medium was replaced with either differentiation or non-differentiation media. These consist of FBS-free DMEM/F12 media containing insulin $(5 \mu \mathrm{g} / \mathrm{ml})$, hydrocortisone $(1 \mu \mathrm{g} / \mathrm{ml})$ and either supplemented with or lacking ovine prolactin $(3 \mu \mathrm{g} / \mathrm{ml})$ respectively, and supplemented with gentamicin $(50 \mu \mathrm{g} / \mathrm{ml})$. Media were changed on daily basis.

\section{ET treatment}

Two modes of ET treatments were applied. For cell viability experiments, cells plated on EHS-drip were supplemented with $0.5,5,10,50$ and $500 \mu \mathrm{g} / \mathrm{ml}$ ET on day 1 of culture. The medium supplemented with ET was changed on a daily basis for up to 6 days in culture (or 5 days post ET treatment). Cell counting was done on days 2, 4 and 6 of culture. Cells were washed twice with HBSS and then trypsin-EDTA was added at $37^{\circ} \mathrm{C}$, until all the cells detached. The dissociated viable cells were then counted using trypan blue staining (Tarraf et al. 2003). Triplicate wells were counted for each concentration of ET at each time point.

For all other experiments, the cells were allowed to grow in ET-free growth medium on EHS-drip or plastic until they reached confluence. Then, they were shifted to differentiation media, supplemented with 1\% FBS, and were treated with either $0.01,0.1,1,5,10$ or $50 \mu \mathrm{g} / \mathrm{ml}$ ET, and samples were collected at 3, 6, 9, 12, 15, 18, 24 and $48 \mathrm{~h}$ depending on the experiment and as indicated in the text and respective figure legends. 


\section{NF- $\kappa$ B electrophoretic mobility shift assay (EMSA)}

CID-9 cells, cultured on EHS-drip, were washed twice in $5 \mathrm{ml}$ ice-cold PBS, and the cells were collected (gently scraped by a rubber policeman) and centrifuged at $420 \mathrm{~g}$ for $5 \mathrm{~min}$ at $4{ }^{\circ} \mathrm{C}$. Cell membranes were lysed, and hence nuclei were released, by resuspending the pellet in $250 \mu \mathrm{l}$ buffer A $(10 \mathrm{mM}$ Tris $-\mathrm{HCl} \mathrm{pH} 7.8,10 \mathrm{mM} \mathrm{KCl}$, $1.5 \mathrm{mM} \mathrm{MgCl}_{2}$, and one tablet Complete Protease Inhibitors $/ 30 \mathrm{ml}$ buffer). The suspension was left on ice for $10 \mathrm{~min}$ followed by a $45 \mathrm{~s}$ homogenization at a moderate speed (15000 r.p.m.), using a Polytrone (Kinametica, Littau-Luzern, Switzerland). The nuclei were collected by centrifugation at $4500 \mathrm{~g}$ for $5 \mathrm{~min}$ at $4{ }^{\circ} \mathrm{C}$, and then lysed by resuspension in $100 \mu \mathrm{l}$ buffer $\mathrm{B}(20 \mathrm{mM}$ Tris $-\mathrm{HCl}, \mathrm{pH}$ $7.8,420 \mathrm{mM} \mathrm{KCl}, 1.5 \mathrm{mM} \mathrm{MgCl} 2,20 \%$ glycerol and one tablet Complete Protease Inhibitors $/ 30 \mathrm{ml}$ buffer), with gentle agitation at $4{ }^{\circ} \mathrm{C}$ for $30 \mathrm{~min}$. The debris was cleared by centrifugation at $10000 \mathrm{~g}$ for an additional $30 \mathrm{~min}$ at $4{ }^{\circ} \mathrm{C}$, and the supernatant was stored at $-70^{\circ} \mathrm{C}$ until used. On the day of the assay, protein quantification, using the microtiter Bradford assay, was performed for the samples, using BSA as a standard.

EMSAs were performed using a ${ }^{32} \mathrm{P}$-radiolabeled deoxyoligonucleotide sequences (from Sigma-Genosys, Cambridge, UK) of NF-kB-binding DNA: W-22, 5'-AGTTGAGGGGACTTTCCCAGGC-3' (consensus sequence italicized) and M-22 (1-pb missense control), 5'-AGTTGAGGCGACTTTCCCAGGC-3'.

After end labeling with polynucleotide kinase purifying and annealing probes, identical amounts of radioactivity $\left(2 \times 10^{4}\right.$ counts/min) were added to the binding reactions containing $10 \mu \mathrm{g}$ cell nuclear extracts in a final volume of $40 \mu \mathrm{l}$ in DNA-binding buffer (20 mM Hepes, $\mathrm{pH} 7.9$, $1 \mathrm{mM} \mathrm{MgCl} 2$, and $4 \%$ Ficoll) containing $0.15 \mu \mathrm{g}$ poly(dl$\mathrm{dC})$ as a non-specific competitor. The mixtures were incubated for $30 \mathrm{~min}$ before separation on non-denaturing $4 \%$ polyacrylamide gels at room temperature by electrophoresis in Tris-borate-EDTA buffer.

As a control of the specificity of the band, non-labeled oligonucleotide competitors were added in 100-fold molar excess immediately before the addition of a radiolabeled probe of the same sequence. For supershift experiments, specific antibodies for NF- $\mathrm{B}$ (polyclonal rabbit p50, p52 or p60, anti-NF-кB IgG) were added, at $2 \mu \mathrm{g} /$ reaction, to the samples, $30 \mathrm{~min}$ before the addition of the labeled probe.

Distribution of ${ }^{32} \mathrm{P}$-labeled bands was visualized by autoradiography and the autoradiograms were scanned and quantified using $\mathrm{NIH}$ Image 1.62 software (http://rsb.info.nih.gov/nih-image/). The arbitrary values obtained from the scanning were plotted as percentage of control at each time point.

\section{RNA extraction and Northern blotting}

For RNA extraction, CID-9 cells were seeded on EHS-drip with differentiation media as described above, and treated with different ET concentrations of $0.01,1,5$ and $10 \mu \mathrm{g} / \mathrm{ml}$ on day 4 of culture. Twenty-four and $48 \mathrm{~h}$ post ET treatment, total cellular RNA was extracted from ETtreated cultured CID-9 cells and control untreated CID cells according to Chomczynski \& Sacchi (1987). Northern analysis for $\beta$-casein was performed as described by El-Sabban et al. (2003).

\section{Protein extraction and Western blotting}

CID-9 cells were cultured on EHS-drip, with differentiation media and treated with $0.01,0.1,1$ and $5 \mu \mathrm{g} / \mathrm{ml}$ ET on day 4 of culture. Protein extraction was done on day 6 of culture ( $48 \mathrm{~h}$ post ET treatment) by scraping the cells into lysis buffer $(50 \mathrm{mM}$ Tris- $\mathrm{HCl}, \mathrm{pH} 7.5,150 \mathrm{mM} \mathrm{NaCl}$, $1 \%$ Nonidet P40, $0.5 \%$ sodium deoxycholate) and shearing them several times through a 21-gauge needle. Complete Protease Inhibitors were added in a concentration of $40 \mu$ l (of one Complete Protease Inhibitor tablet dissolved in $2 \mathrm{ml}$ water) per $1 \mathrm{ml}$ lysis buffer, and the cell extracts were centrifuged at $15000 \mathrm{~g}$. The supernatants were resolved on an equal protein basis as determined by BioRad assay with BSA as a standard, on $12 \%$ polyacrylamide gel under denaturing conditions. After electrophoresis, resolved proteins were transferred to Immobilin-P membranes using a wet blot apparatus (Hoefer Scientific Instruments, San Francisco, CA, USA) with a transfer buffer (39 mM glycine, $48 \mathrm{mM}$ Tris base, $0.037 \%$ SDS, $20 \%$ methanol). Membranes were blocked overnight in a wash buffer $(100 \mathrm{mM}$ Tris-HCl buffer, $\mathrm{pH} 7.5,150 \mathrm{mM} \mathrm{NaCl}$, $0.3 \%$ Tween 20 ) with $2 \%$ fatty acid-free BSA. The membranes were then incubated for $1 \mathrm{~h}$ in polyclonal rabbit anti-mouse milk antiserum (diluted 1:10000 in blocking buffer) and washed three times, for $20 \mathrm{~min}$ each, to remove unbound antiserum, and then placed in the secondary antibody (horseradish peroxidase-conjugated antirabbit) at a dilution of 1:5000 for $1 \mathrm{~h}$ at room temperature while shaking. Finally, membranes were washed three times (20 min per wash). This step was followed by the use of enhanced chemiluminescence using the ECL system in conjunction with horseradish peroxidase-conjugated secondary antibodies. Membranes were then exposed to X-ray films for varying time periods. All washings and incubations were done at room temperature.

\section{Substrate-gel electrophoresis}

Media were sampled from cultures treated with different ET concentrations, and from control cultures, at different time points. The samples were stored at $-70{ }^{\circ} \mathrm{C}$ until the day of the assay. Gelatinase activity in medium samples was analyzed with minor modifications of the method described by Talhouk et al. (1991). Equal sample volumes were loaded and run on $7 \%$ polyacrylamide gels impregnated with gelatin $(3 \mathrm{mg} / \mathrm{ml})$. The gels were run in $1 \times$ electrophoresis running buffer $(0.0025 \mathrm{M}$ Tris $-\mathrm{HCl}, \mathrm{pH}$ 8.3, $0.192 \mathrm{M}$ glycine, $0.1 \%$ SDS). After electrophoresis, the gels were washed twice consecutively for $30 \mathrm{~min}$, 
at room temperature, in a $2.5 \%$ Triton $\mathrm{X}-100$ solution in running buffer. After washing, the gels were incubated for $24 \mathrm{~h}$ in substrate buffer $(50 \mathrm{mM}$ Tris- $\mathrm{HCl}, 5 \mathrm{mM} \mathrm{CaCl}$, $\left.0.02 \% \mathrm{NaN}_{3}, \mathrm{pH} 8.0\right)$ at $37^{\circ} \mathrm{C}$. The gels were then stained for $2 \mathrm{~h}$, at room temperature, in $0.05 \%$ Coomassie blue R250 , in $50 \%$ methanol and $10 \%$ acetic acid. The gels were then destained in water overnight. The gelatinases were visualized as clear white bands on darkly stained blue gels. Photographs of substrate gels are shown as negative images.

\section{ELISA}

Media were sampled from cultures treated with different ET concentrations, and from control cultures, at different time points. Complete Protease Inhibitors were added to the samples and were stored at $-70^{\circ} \mathrm{C}$ until assayed.

The concentration of IL- 6 and TNF- $\alpha$ in the medium samples was measured using a modification of a two-site (sandwich) ELISA as described previously (Safieh-Garabedian et al. 1995). Immunoaffinity-purified polyclonal sheep anti-mouse IL- 6 or TNF- $\alpha$ antibodies were used to coat high-binding 96-well microtiter plates (Immunoplate MaxiSorp; NUNC, Rockslide, Denmark). Recombinant mouse IL-6 or TNF- $\alpha$ was used as the standard, and a biotinylated immunoaffinity-purified polyclonal sheep anti-mouse IL- 6 and TNF- $\alpha$ as a recognition antibody respectively. All wells were coated $(100 \mu \mathrm{l} /$ well $)$ with the coating antibody $(2 \mu \mathrm{g} / \mathrm{ml}$ in bicarbonate coating buffer) and were incubated overnight at $4{ }^{\circ} \mathrm{C}$. The plates were then washed four times $(300 \mu \mathrm{l} /$ well $)$ with wash/dilution buffer. The plate wells were then blocked with blocking buffer $(3 \%$ BSA in PBS) $(300 \mu \mathrm{l} /$ well); the plate was then incubated at $37^{\circ} \mathrm{C}$ for $1 \mathrm{~h}$. While incubating the plate, the standard dilutions were prepared ranging from 1000 to $1.9 \mathrm{pg} / \mathrm{ml}$ in wash/dilution buffer. After washing as described the medium samples were used as such without diluting them. The standard dilutions and the samples were added in duplicates $(100 \mu \mathrm{l} /$ well). The blank wells received wash/dilution buffer. The plates were incubated at $4{ }^{\circ} \mathrm{C}$ overnight and washed as previously described, and the biotinylated antibody was diluted 1:4000 in 1\% normal sheep serum in wash/dilution buffer and added $\left(100 \mu \mathrm{l} /\right.$ well). The plates were then incubated at $4{ }^{\circ} \mathrm{C}$ overnight, washed, and $100 \mu \mathrm{l} /$ well strepavidin-horseradish peroxidase (Amersham Pharmacia Biotech) diluted 1:8000 in wash/dilution buffer were added. The plates were then incubated at room temperature, washed and the chromogen $\left(500 \mu \mathrm{l} \quad 3,3^{\prime}, 5,5^{\prime}\right.$-tetramethylbenzidine $+6 \mu \mathrm{l} \quad 30 \%$ $\mathrm{H}_{2} \mathrm{O}_{2}+5 \mathrm{ml}$ acetate buffer in $45 \mathrm{ml}$ water) was added to all wells $(100 \mu \mathrm{l} /$ well $)$. The plates were kept in the dark at room temperature for $10-15 \mathrm{~min}$. The reaction was then stopped by the addition of $1 \mathrm{M} \mathrm{H}_{2} \mathrm{SO}_{4}(100 \mu \mathrm{l} /$ well $)$. The optical density was read by a plate reader (Dynatech Medical Products Limited, Billinghurst, UK) using a $450 \mathrm{~nm}$ filter.

NGF was assayed using a Promega $E_{\max }$ Immunoassay System (Promega Corporation, Madison, WI, USA), following the protocol provided in the kit's Technical Bulletin. Triplicate wells were assayed for each concentration of ET at each time point.

\section{Data analysis}

Cell numbers were analyzed in triplicate as a completely randomized design over days with six treatments: control, $0.5,5,10,50$ and $500 \mu \mathrm{g} / \mathrm{ml}$ ET. Means were separated according to the least significant difference (LSD) test. Significant differences between average levels of cytokines and NGF were determined after appropriate ANOVA using Tukey's test. All analyses were performed using SPSS 11.5 (SPSS 2002).

\section{Results \\ The effect of ET on CID-9 cell morphology and viability}

To determine the effect of ET concentrations on CID-9 cell viability, different ET concentrations of 0.5, 5, 10, 50 and $500 \mu \mathrm{g} / \mathrm{ml}$ were added daily to CID-9 cells plated on EHSdrip. Cell count was assessed daily over a period of 5 days post ET treatment. ET significantly affected the cell number within each day as indicated by ANOVA (data not shown). Cell count and viability were not significantly affected when cells were treated with $0.5,5$ and $10 \mu \mathrm{g} / \mathrm{ml}$ ET, throughout the 5 day treatment of the cells with ET. This was in contrast to the effect of ET at the higher concentrations of 50 and $500 \mu \mathrm{g} / \mathrm{ml}$. At $50 \mu \mathrm{g} / \mathrm{ml}$, approximately $60 \%$ of the cells remained attached and were viable as noted by the decrease in cell count by day 5 post ET treatment, whereas at $500 \mu \mathrm{g} / \mathrm{ml}$, ET was highly toxic to the cells and only about $20 \%$ of the cells were attached and viable by day 5 post ET treatment (Fig. 1). Similar results were obtained when the cells were plated on plastic (data not shown). The data clearly demonstrated that low concentrations of ET, such as 0.5, 5 and $10 \mu \mathrm{g} / \mathrm{ml}$, do not affect the viability and growth morphology of CID-9 cells up to at least 5 days post ET treatment. Based on the above, cells were treated in all the following experiments upon confluence with a single dose of ET at concentrations of $10 \mu \mathrm{g}$ or less and for periods extending from 1 to $48 \mathrm{~h}$, depending on the type of the assay used.

\section{ET induces NF- $\kappa B$ nuclear translocation and activation in CID-9 cells}

One of the main markers for a cell response to ET is the activation and nuclear translocation of NF-кB. EMSA was performed on nuclear extracts at 1 and $3 \mathrm{~h}$ post ET treatment with different ET concentrations of $0.01,0.1,1$ and $10 \mu \mathrm{g} / \mathrm{ml}$. The activation of NF-кB by ET in CID-9 cells was noted within $1 \mathrm{~h}$ of exposure. Maximal stimulation was reached at $1 \mathrm{~h}$ with $10 \mu \mathrm{g} / \mathrm{ml}$ ET (Fig. 2A). The shifted bands were quantified using a densitometer, and the 


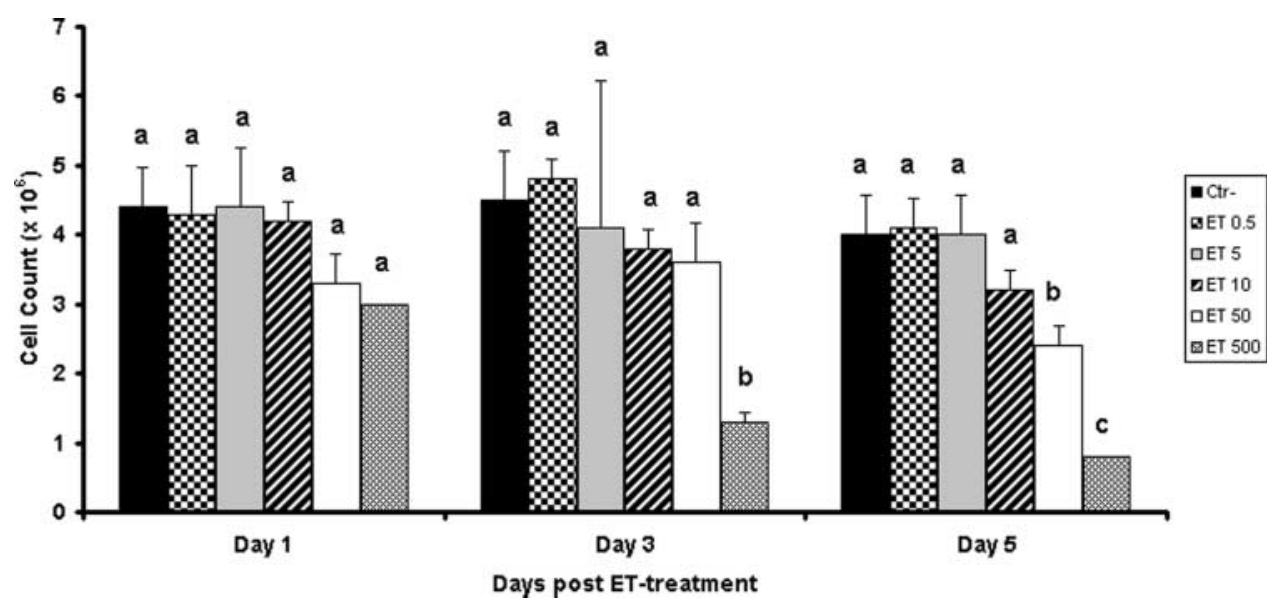

\begin{abstract}
Figure 1 Bar graphs showing viable counts of CID-9 cells cultured in differentiation medium on EHS-drip and treated with different ET concentrations $(\mu \mathrm{g} / \mathrm{ml})$. The values are the average of triplicate wells ( \pm S.D.). Means within the same day, with the same letter, are not significantly different according to the LSD test $(P \leq 0.05)$.
\end{abstract}

arbitrary values resulting there from were represented as the percentage of activation of each sample relative to the bands obtained with the control at each time point (Fig. 2B). At 6, 9 and $12 \mathrm{~h}$, no activation of NF-кB was evident (data not shown).

In order to explore the type of NF-кB dimers involved in the CID-9 cell activation process, supershift experiments were performed using specific antibodies for NF-кB subunits p50, p52 or p60. These experiments

A

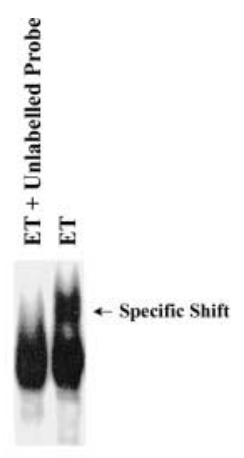

B

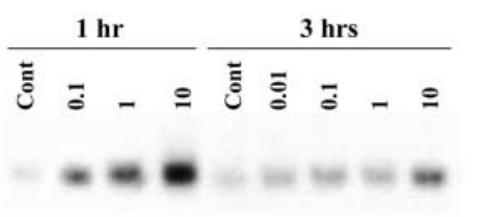

C

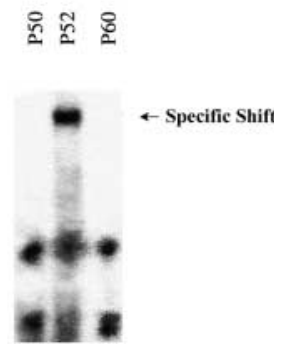

Figure 2 (A) A representative EMSA showing the activation of NF- $\mathrm{kB}$ with increasing ET concentrations $(0.01,0.1,1,10 \mu \mathrm{g} / \mathrm{ml})$, at 1 and $3 \mathrm{~h}$. The maximum activity is observed at $1 \mathrm{~h}$ post exposure to ET. The signal of NF-kB in the $10 \mu \mathrm{g} / \mathrm{ml}$ ET-treated CID-9 cell nuclear extract, at $1 \mathrm{~h}$, is inhibited by 100 -fold addition of the unlabelled probe. (B) Graphic analysis of ET-induced NF- $\mathrm{kB}$ activation, as determined by densitometric quantification of the shifted bands, plotted as percentage of control (the ET concentrations are in $\mu \mathrm{g} / \mathrm{ml}$ ). (C) Supershift analysis by selective antibodies raised against the NF-кB subunits p50, p52 and p60 revealed the presence of the subunit p52 in the nucleus. demonstrated that p52, and not p50 or p60, was activated in response to $10 \mu \mathrm{g} / \mathrm{ml}$ ET treatment (Fig. 2C).

\section{The effect of ET on $\beta$-casein and gelatinase expression CID-9 cells}

ET inhibited in a dose-dependent manner $\beta$-casein expression by CID-9 cells plated on EHS-drip. The expression of $\beta$-casein was assessed in samples extracted from confluent CID-9 cells plated on EHS-drip and treated with different ET concentrations. Northern blot analysis was performed on total RNA, extracted on day 1 or 2 post ET treatment (Fig. 3A and B respectively). Western blot analysis was done on protein samples, extracted on day 2 post ET treatment (Fig. 3C). Both Northern blot analysis at days 1 and 2 post ET treatment and Western blots analysis at 2 days post ET treatment showed that ET decreased $\beta$ casein mRNA and protein levels respectively in CID-9 cells and in a dose-dependent manner.

In addition, substrate-gel electrophoresis showed that both the 72 and $92 \mathrm{kDa}$ gelatinase activities increased in CID-9 cells cultured on EHS-drip by 24 and $48 \mathrm{~h}$ post ET treatment at 10 and $50 \mu \mathrm{g} / \mathrm{ml}$. The gelatinase activity was higher in the $50 \mu \mathrm{g} / \mathrm{ml}$ ET-treated CID-9 cells and the activation of the $72 \mathrm{kDa}$ gelatinase, which is revealed by the appearance of a $64 \mathrm{kDa}$ fragment, was noted $48 \mathrm{~h}$ post ET treatment (Fig. 4).

\section{The effect of the ET on cytokine and NGF production in CID-9 cells}

ET stimulatory effect on cytokine TNF- $\alpha$ and IL- 6 was noted as early as $1 \mathrm{~h}$ post ET treatment, while an NGF increase due to ET was noted at 6 and $9 \mathrm{~h}$. TNF- $\alpha$ ELISA revealed that $\mathrm{ET}$ treatment stimulated the production of this cytokine in cells cultured on plastic (Fig. 5Ai) and on EHS-drip (Fig. 5Aii). The secretion of TNF- $\alpha$ started to increase by $1-3 \mathrm{~h}$ post treatment, and reached a maximal level by $6 \mathrm{~h}$. This increase was dose-dependent, showing maximum levels of TNF- $\alpha$ with $10 \mu \mathrm{g} / \mathrm{ml} \mathrm{ET}$. 
A

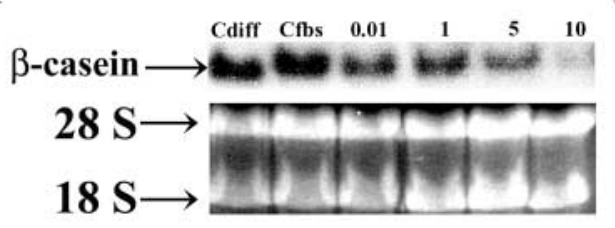

C

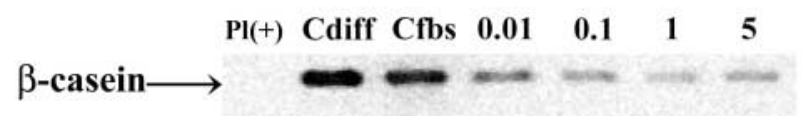

B $\begin{array}{lllll}\text { Cfbs } & 0.01 & 1 & 5 & 10\end{array}$

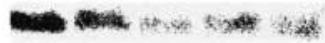

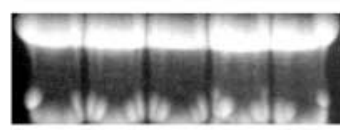

Figure 3 Northern blot analysis of $\beta$-casein mRNA in CID-9 cells on EHS-drip on day 1 (A) and day 2 (B) post ET treatment. (C) Western blot analysis of $\beta$-casein in CID-9 cells on day 2 post ET treatment. (Cdiff: control cells receiving differentiation medium only; Cfbs: control cells receiving differentiation medium supplemented with $\mathrm{FBS} ; \mathrm{Pl}(+)$ : cells on plastic with differentiation medium (negative control). Arabic numerals appearing above lanes indicate concentration $(\mu \mathrm{g} / \mathrm{ml})$ of ET.

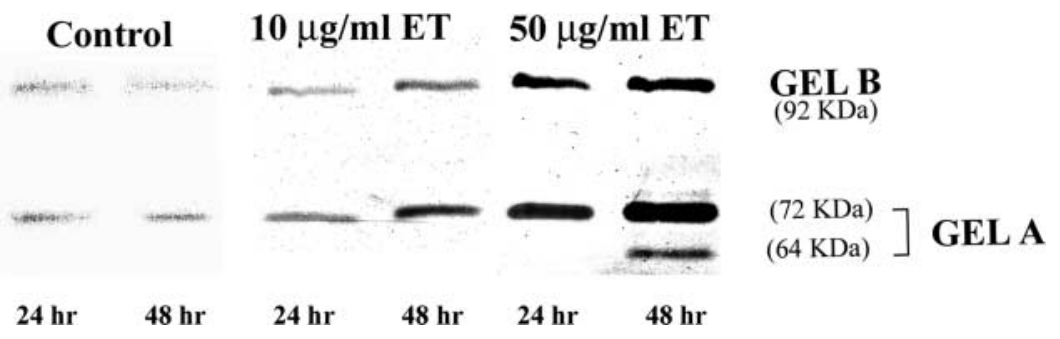

Figure 4 Gelatinase zymography of samples taken from CID-9 cell conditioned media 24 and $48 \mathrm{~h}$ post ET treatment of CID-9 cells on EHS-drip. Note increased gelatinase activity in 10 and $50 \mu \mathrm{g} / \mathrm{ml}$ ET-treated cells compared with control non-treated cells.
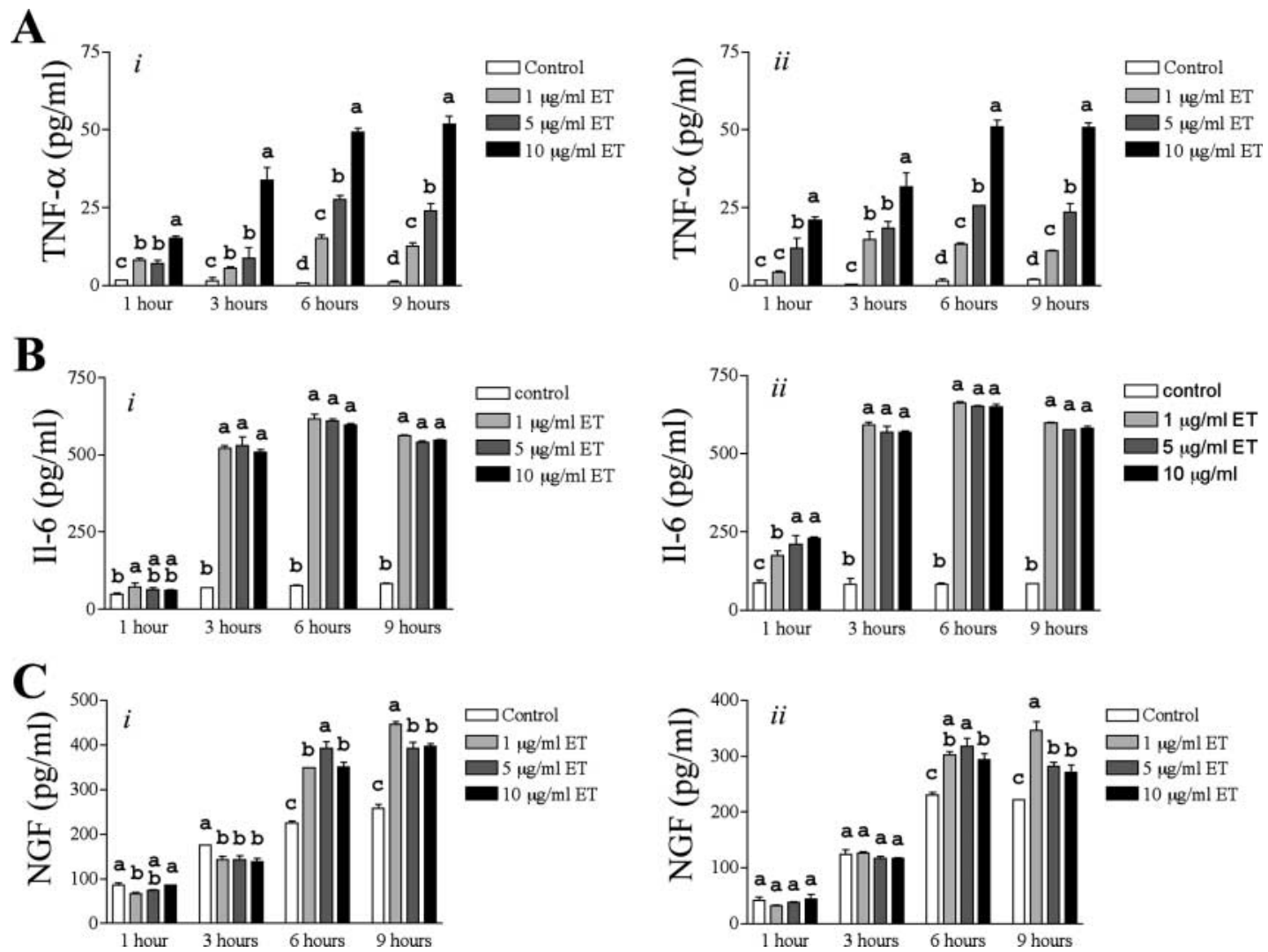

Figure 5 TNF- $\alpha$ (A), IL-6 (B) and NGF (C) ELISA for CID-9 cells cultured on plastic (i) or on EHS-drip (ii) and treated with different concentrations of ET. The values are the average of triplicate samples ( \pm S.D.). Means within the same time post ET treatment, with the same letter, are not significantly different. 
The effect of ET on the levels of IL-6, in CID-9 cells, was similar to that of TNF- $\alpha$. IL- 6 assays demonstrated that different ET concentrations induced the production of this cytokine by CID-9 cells cultured on plastic (Fig. 5Bi) and on EHS-drip (Fig. 5Bii) at $1-3 \mathrm{~h}$ post ET treatment. In fact, by $6 \mathrm{~h}$ post treatment with 1, 5 and $10 \mu \mathrm{g} / \mathrm{ml} \mathrm{ET,} \mathrm{IL-6}$ levels reached about $600 \mathrm{pg} / \mathrm{ml}$, which is around 8 -fold higher than the levels observed in controls. The control untreated cells maintained a constant basal level less then $100 \mathrm{pg} / \mathrm{ml}$ in both plastic and EHS-drip cultures.

As detected by NGF assays, non-treated control CID-9 cells increased NGF production in a time-dependent manner. ET enhanced NGF levels in cells cultured on plastic (Fig. 5Ci) and on EHS-drip (Fig. 5Cii), by 6 and $9 \mathrm{~h}$ post ET treatment.

\section{Discussion}

Numerous work has focused on the role immune cells and cytokines play in the initiation and propagation of mammary inflammation (reviewed by Outteridge \& Lee 1981, Riollet et al. 2000). However, few studies aimed to decipher the involvement of non-immune cells, mainly endothelial and epithelial cells, in the inflammatory process (Pugin et al. 1993, Read et al. 1993, Okada et al. 1997, 1999, Yao et al. 1997, Boudjellab et al. 1998, Martin et al. 1998a,b, Rahman 2000). Our study aimed to determine the effect of ET on functional parameters of mammary gland non-immune cells. This may elucidate the role that these cells play in propagating inflammatory signals to the immune system during bacterial infections of the mammary gland, mastitis.

ET is reported to simulate inflammation-like conditions in several in vitro and in vivo models. In vitro, ET was shown to activate primary cultures of alveolar epithelial cells (Haddad et al. 2001), umbilical vein endothelial cells (Pugin et al. 1993, Read et al. 1993), and bovine mammary epithelial cells (Okada et al. 1997, 1999, Boudjellab et al. 1998), in addition to stimulating macrophages (Morris et al. 1992, Morrison et al. 1994), T cells (Mattern et al. 1994) and B cells (Sibley et al. 1988) from different species. In vivo, when introduced in the mammary gland, ET induced mastitis in several animal models, such as sheep (Colditz 1987), goat (Dhondt et al. 1977, Lengemann \& Pitzrick 1987) and cows (Oliver \& Smith 1982, Shuster et al. 1993).

CID-9 cells acquire a differentiated phenotype in response to cell-ECM, and cell-cell interaction and to lactogenic hormones (Schmidhauser et al. 1990, El-Sabban et al. 2003). This makes them a suitable model to address the effect of soluble mediators and ET on mammary cell function (Talhouk et al. 2000b 2001). In contrast to other studies on either primary bovine mammary cells or MAC-T bovine epithelial cell line (Boudjellab et al. 1998, Okada et al. 1999) that where limited to monitoring the effect of ET on cytokine production, in this study, we monitored, in addition to cytokine and NGF production, the effect of ET on NF-кB activation and on the differentiation phenotype as indicated by $\beta$-casein and gelatinase expression. The data presented in this study showed that daily exposure of confluent CID-9 cells on EHS-drip to ET concentrations up to $10 \mu \mathrm{g} / \mathrm{ml}$ did not alter the apparent morphology (data not shown) and the viability of CID-9 cells. Moreover, single exposure of CID-9 cells to ET induced NF-кB activation, increased gelatinase activity, inhibited $\beta$-casein expression and stimulated the production of inflammatory cytokines, such as IL-6 and TNF- $\alpha$, and altered NGF production in these cells in a dose-dependent manner.

The optimal ET concentrations that were used to stimulate cells in vitro and the level of cytokines produced vary according to the cell type in question. In other words, distinct cell types are responsive to different ranges of ET concentrations. For instance, immune cells, such as macrophages and lymphocytes, are stimulated by low ET concentrations, in the range of nanograms (Sibley et al. 1988, Morris et al. 1992, Mattern et al. 1994), and produce several-fold the level of cytokines, especially TNF- $\alpha$ and IL-6 (Mullarkey et al. 2003) compared with those produced by epithelial cells. Epithelial cells (Epstein et al. 1990, Wille et al. 1992), on the other hand, including mammary epithelial cells (Boudjellab et al. 1998, Okada et al. 1999) as in this study, require relatively higher concentrations, in the microgram range, to elicit a response that typically does not exceed a few hundred picograms.

The transcription factor NF- $\mathrm{BB}$ is clearly one of the most important regulators of proinflammatory gene expression. It is considered to be a marker for cell activation by ET (Read et al. 1993). Translocation of NF-кB to the nucleus leads to subsequent activation of several genes involved in the inflammatory process including cytokines TNF- $\alpha$, IL$1 \beta$, IL- 6 and IL-8, cytokine receptors and MMPs (Baldwin 1996, Yokoo \& Kitamura 1996, Han et al. 1998, Mengshol et al. 2000). In addition, as shown in this study, it also leads to the downregulation of $\beta$-casein expression at both the mRNA and protein level. We suggest this occurs by either of two pathways. Previous studies on the mammary gland reported that NF- $\mathrm{KB}$ is involved in regulating $\beta$-casein expression (Doppler et al. 2000). NF-кB activation inhibits the prolactin-induced $\beta$-casein expression by either inhibiting STAT5 tyrosine phosphorylation, which is an essential step for its activation (Yang et al. 2000), or NF-кB can inhibit STAT5 from binding to the $\beta$ casein gene promoter region by allosteric hindrance due to overlapping binding sites for STAT5 and NF-кB in the $\beta$-casein gene promoter (Doppler et al. 2000, Geymayer $\&$ Doppler 2000). In other words, by inhibiting $\beta$-casein expression, ET puts the CID-9 cells in a de-differentiated state. This occurs in parallel to an increased cytokine and gelatinase production by these cells.

Alternatively, the expression of the MMPs by mammary epithelial cells was previously reported to directly affect casein expression and the differentiation of the mammary gland. In fact, a coordinated balance between MMPs and 
their inhibitors is crucial to ensure normal development and differentiation of the mammary gland. The increased expression of stromelysin and type IV collagenase during involution of the mammary gland leads to degradation of the basement membranes and loss of $\beta$-casein expression (Talhouk et al. 1992, Sympson et al. 1994) and triggers apoptotic events (Strange et al. 1992, Boudreau et al. 1995). Whether the ET-induced gelatinase expression and loss of $\beta$-casein expression are independent events induced by NF-KB activation or whether the increased gelatinase leads to loss of $\beta$-casein expression and apoptosis was not clear from our studies.

Okada et al. (1997) reported that bovine mammary primary cells sustain IL- 6 and IL- 1 production until day 14 in culture. Recently, it has been shown that ET increased the production of these cytokines in culture (Okada et al. 1999). In our study neither IL-1 $\beta$, nor IL-4, IL-10 or IL-18 were detected in ET-treated or non-treated cultures (data not shown), while only IL-6, TNF- $\alpha$ and NGF production were enhanced upon ET treatment. The discrepancy could be due to species differences, or due to the fact that the primary culture preparation of Okada et al. $(1997,1999)$ was not devoid of immune cells, which contributed to the reported IL-1 levels. Alternatively, the levels of IL-1 cytokines, and for that matter, the levels of IL-4, IL-10 or IL18 , in our culture system were below the detection limit of the assays used in this study. No previous reports have demonstrated NGF production by mammary cells. However, the role of NGF in ET-induced inflammation and hyperalgesia has been well documented. Our laboratory reported earlier that intra-plantar injections of ET induced local inflammation in rats and increased NGF levels. The levels of NGF were reduced upon treatment of the rats with analgesics or anti-inflammatory drugs (Safieh-Garabedian et al. 1996, 1997). Based on that we speculate that the role of increased NGF levels by mammary cells upon exposure to $E T$, as in the case during mastitis, may be involved in nociception. Boudjellab et al. (1998) showed that a bovine mammary epithelial cell line (MAC-T) expresses IL-8 upon ET stimulation. No attempts to assay for IL-8 were undertaken in our study.

Due to the fact that CID-9 mammary cells are a heterogeneous population, the cellular source of the cytokines and NGF in culture, as assessed by ELISA, cannot be determined. However, mammary SCp2 cells (epithelial sub-clones of CID-9 mammary cells (Desprez et al. 1993)) grown in culture under the same conditions as CID-9 cells produce cytokines in comparable levels and patterns in response to ET stimulation (data not shown); thus we speculate that the cytokines produced in culture in response to ET may be products of the epithelial cell component of CID-9 cells.

In conclusion, ET-treated CID-9 cells suppress $\beta$-casein expression and upregulate markers of de-differentiation, such as gelatinases and cytokines, which are involved in stimulating and recruiting immune cells to the site of infection in vivo (Shuster et al. 1993). This study suggests that mammary cells may participate in the immune reaction elicited by mammary gland, in vivo, in response to an ET challenge, mastitis, or during involution (Oliver \& Smith 1982, Colditz 1987, Persson et al. 1992, Schanbacher et al. 1993, 1997). This model could be used to further decipher how ET modulates casein expression and markers of de-differentiation of mammary cells in culture and to investigate the effect of candidate molecules for their potential anti-inflammatory properties, during mastitis.

\section{Acknowledgements}

The authors are thankful for Dr Riad Baalbaki for assisting in the statistical analysis. Khaled Mussawi and Marie-Therese Rached are acknowledged for assisting in the preparation of the manuscript. This work is supported by the University Research Board (R T and B S-G), Lebanese National Council for Scientific Research (R T), and the Mercy Corps/Lebanon Program, award No. RA:M01/12 (R T).

\section{References}

Baldwin AS Jr 1996 The NF-кB and ІкB proteins: new discoveries and insights. Annual Reviews in Immunology 14 649-681.

Baldwin AS Jr 2001 The transcription factor NF-кB and human disease. Journal of Clinical Investigation 107 3-6.

Bondeson J, Foxwell B, Brennan F \& Feldmann M 1999 Defining therapeutic targets by using adenovirus: blocking NF-кB inhibits both inflammatory and destructive mechanisms in rheumatoid synovium but spares anti-inflammatory mediators. PNAS 96 5668-5673.

Boudjellab N, Chan-Tang HS, Li X \& Zhao X 1998 Interleukin 8 response by bovine mammary epithelial cells to lipopolysaccharide stimulation. American Journal of Veterinary Research $\mathbf{5 9}$ $1563-1567$.

Boudreau N, Sympson CJ, Werb Z \& Bissell MJ 1995 Suppression of ICE and apoptosis in mammary epithelial cells by extracellular matrix. Science 267 891-893.

Chomczynski P \& Sacchi N 1987 Single-step method of RNA isolation by acid guanidinium thiocyanate-phenol-chloroform extraction. Analytical Biochemistry 162 156-159.

Colditz IG 1987 Induction of inflammatory responses by endotoxin in the non-lactating ovine mammary gland. Immunology and Cell Biology 65 437-441.

Colditz IG, Zwahlen RD \& Baggiolini M 1990 Neutrophil accumulation and plasma leakage induced in vivo by neutrophil-activating peptide-1. Journal of Leukocyte Biology 48 129-137.

Desprez PY, Roskelley C, Judith C \& Bissell MJ 1993 Isolation of functional cell lines from a mouse mammary epithelial cell strain: the importance of basement membrane and cell-cell interaction. Molecular and Cellular Differentiation 199-110.

Dhondt G, Burvenich C \& Peeters G 1977 Mammary blood flow during experimental Escherichia coli endotoxin induced mastitis in goats and cows. Journal of Dairy Research 44 433-440.

Doppler W, Geymayers S \& Weirich HG 2000 Synergistic and antagonistic interactions of transcription factors in the regulation of milk protein gene expression. Mechanism of cross-talk between signaling pathways. Advances in Experimental Medicine and Biology 480 139-146.

El-Sabban M, Sfeir A, Daher M, Kalaany N, Bassam R \& Talhouk R 2003 Gap junctional communication induces $\beta$-casein expression in mammary epithelial cells in the absence of cell/ECM interaction. Journal of Cell Science 116 3531-3541.

Epstein J, Lee MM, Kelly CE \& Donahue PK 1990 Effect of E. coli endotoxin on mammalian cell growth and recombinant protein 
production. In Vitro Cellular and Developmental Biology 26 $1121-1122$.

Gearing AJ, Beckett P, Christodoulou M, Churchill M, Clements J, Davidson AH, Drummond AH, Galloway WA, Gilbert R, Gordon JL, Leber TM, Mangen M, Miller K, Nayee P, Owen K, Patel S, Thomas W, Wells G, Wood LM \& Wooley K 1994 Processing of tumour necrosis factor-alpha precursor by metalloproteinases. Nature 370 555-557.

Geymayer S \& Doppler W 2000 Activation of NF-kappa B P50/P65 is regulated in the developing mammary gland and inhibits STAT5mediated beta-casein gene expression. FASEB Journal $\mathbf{1 4}$ 1159-1170.

Haddad JJ, Lauterbach R, Saade NE, Safieh-Garabedian B \& Land SC 2001 Alpha-melanocyte-related tripeptide, Lys-D-Pro-Val, ameliorates endotoxin-induced nuclear factor kappaB translocation and activation: evidence for involvement of an interleukin-1beta193195 receptor antagonism in the alveolar epithelium. Biochemical Journal 355 29-38.

Han ZN, Boyle DL, Manning AM \& Firestein GS 1998 AP-1 and NFkappa $B$ regulation in rheumatoid arthritis and murine collageninduced arthritis. Autoimmunity 28 197-208.

Homaidan FR, Desai H, Zhao L, Broutman G \& Burakoff R 1995 Regulation of electrolyte transport with IL-1 $\beta$ in the rabbit distal colon. Mediators of Inflammation 4 61-66.

Homaidan FR, Zhao L, Chakroun I, Martin CA \& Burakoff R 1999 The mechanism of action of interleukin-1 on rabbit intestinal epithelial cells. Mediators of Inflammation 8 189-197.

Inch S \& Fisher C 1995 Mastitis: infection or inflammation? The Practitioner 239 472-476.

Jackson JA, Shuster DE, Silvia WJ \& Harmon RJ 1990 Physiological responses to intramammary or intravenous treatment with endotoxin in lactating dairy cows. Journal of Dairy Sciences $\mathbf{7 3}$ $627-632$.

Kim H \& Koh G 2000 Lipopolysaccharide activates matrix metalloproteinase-2 in endothelial cells through an NF-kappaB-dependent pathway. Biochemical and Biophysical Research Communications 269 401-405.

Lee JD, Kravchenko V, Kirkland TN, Han J, Mackman N, Moriarty A, Leturcq D, Tobias PS \& Ulevitch RJ 1993 Glycosylphosphatidylinositol-anchored or integrated membrane forms of CD14 mediated cellular responses to endotoxin. PNAS 90 9930-9934.

Lengemann FW \& Pitzrick M 1987 Endotoxin of Escherichia coli and permeability of the mammary gland of goats. Journal of Dairy Sciences 70 201-208.

Martin CA, El-Sabban ME, Zhao LM, Burakoff $R$ \& Homaidan FR 1998a Adhesion and cytosolic dye transfer between macrophages and intestinal epithelial cells. Cell Adhesion and Communication $583-95$.

Martin CA, Homaidan FR, Zhao LM, Burakoff R \& El-Sabban ME $1998 b$ Gap junctional communication between macrophages and intestinal epithelial cells. Cell Adhesion and Communication 5 437-449.

Mattern T, Thanhauser A, Reiling N, Toellner K, Duchrow $M$, Kusumoto S, Rietschel ET, Ernst M, Brade H, Flad HD \& Ulmer AJ 1994 Endotoxin and lipid A stimulate proliferation of human T cells in the presence of autologous monocytes. Journal of Immunology 153 2996-3004.

Mengshol JA, Vincenti MP, Coon Cl, Barchowsky A \& Brincherhoff CE 2000 Interleukin-1 induction of collagenase 3 (MMP13) gene expression in chondrocytes requires P38, c-Jun $\mathrm{N}$-terminal kinase, and nuclear factor-kappa B: differential regulation of collagenase 1 and collagenase 3. Journal of Arthritis and Rheumatism 43 801-811.

Morris DD, Crowe N, Moore JN \& Moldawer LL 1992 Endotoxininduced production of interleukin 6 by equine peritoneal macrophages in vitro. American Journal of Veterinary Research $\mathbf{5 3}$ 1298-1301.
Morrison DC, Dinarello CA, Munford RS, Natanson C, Danner R, Pollak M, Spitzer JJ, Ulevitch RJ, Vogel SN \& McSweegan E 1994 Current status of bacterial endotoxins. American Society for Microbiology News $60479-484$.

Mullarkey M, Rose JR, Bristol J, Kawata T, Kimura A, Kobayashi S, Przetak M, Chow J, Gusovsky F, Christ WJ \& Rossignol DP 2003 Inhibition of endotoxin response by e5564, a novel Toll-like receptor 4-directed endotoxin antagonist. Journal of Pharmacology and Experimental Therapeutics 304 1093-1102.

Okada H, Ito T, Ohtsuka H, Kirisawa R, Iwai H, Yamashita K, Yoshino T \& Rosol TJ 1997 Detection of interleukin-1 and interleukin-6 on cryopreserved bovine mammary epithelial cells in vitro. Journal of Veterinary Medical Sciences 59 503-507.

Okada H, Ohtsuka H, Kon-Nai S, Kirisawa R, Yokomizo Y, Yoshino T \& Rosol TJ 1999 Effects of lipopolysaccharide on production of interleukin- 1 and interleukin- 6 by bovine mammary epithelial cells in vitro. Journal of Veterinary Medical Sciences $6133-35$.

Oliver SP \& Smith KL 1982 Bovine mammary involution following intramammary infusion on colchicine and endotoxin at drying off. Journal of Dairy Sciences 65 801-813.

Outteridge PM \& Lee CS 1981 Cellular immunity in the mammary gland with particular reference to T, B lymphocytes and macrophages. Advances in Experimental Medicine and Biology 137 513-534.

Persson K, Carlsson A, Hambleton C \& Guidry AJ 1992 Immunoglobulins, lysozyme and lactoferrin in the teat and udder of the dry cow during endotoxin-induced inflammation. Zentralblatt fur Veterinarmedizin [B] 39 165-174.

Pugin J, Schurer-Maly C, Leturcq D, Moriarty A, Ulevitch RJ \& Tobias PS 1993 Lipopolysaccharide activation of human endothelial and epithelial cells is mediated by lipopolysaccharide-binding protein and soluble CD14. PNAS 90 2744-2748.

Rahman I 2000 Regulation of nuclear factor-kappa B, activator protein-1, and glutathione levels by tumor necrosis factor-alpha and dexamethasone in alveolar epithelial cells. Biochemical Pharmacology $601041-1049$.

Read MA, Cordle SR, Veath RA, Carlisle CD \& Hawiger J 1993 Cellfree pool of CD14 mediates activation of transcription factor NF$\kappa \mathrm{B}$ by lipopolysaccharide in human endothelial cells. PNAS 90 9887-9891.

Riollet C, Rainard P \& Poutrel B 2000 Cells and cytokines in inflammatory secretions of bovine mammary gland. In Biology of the Mammary Gland. Advances in Experimental Medicine and Biology, 480, pp 247-257. Eds JA Mol \& RA Clegg. New York: Kluwer Academic/Plenum Publishers.

Safieh-Garabedian B, Poole S, Allchorne A, Winter J \& Woolf CJ 1995 Contribution of interleukin-1 $\beta$ to the inflammation-induced increase in nerve growth factor levels and inflammatory hyperalgesia. British Journal of Pharmacology 115 1265-1275.

Safieh-Garabedian B, Poole S, Allchorne A, Kanaan S, Saade N \& Woolf CJ 1996 Zinc reduces the hyperalgesia and upregulation of NGF and IL-1 beta produced by peripheral inflammation in the rat. Neuropharmacology 35 599-603.

Safieh-Garabedian B, Kanaan SA, Haddad JJ, Jaoude PA, Jabbur SJ \& Saade NE 1997 Involvement of interleukin-1 beta, nerve growth factor and prostaglandin E2 in endotoxin-induced localized inflammatory hyperalgesia. British Journal of Pharmacology 121 1619-1626.

Schanbacher FL, Goodman RE \& Talhouk RS 1993 Bovine mammary lactoferrin: implications from messenger ribonucleic acid (mRNA) sequence and regulation contrary to other milk proteins. Journal of Dairy Sciences 76 3812-3831.

Schanbacher FL, Talhouk RS \& Murray FA 1997 Biology and origin of bioactive peptides in milk. Livestock Production Science $\mathbf{5 0}$ 105-123.

Schmidhauser C, Bissell MJ, Myers CA \& Casperson GF 1990 Extracellular matrix and hormones transcriptionally regulate bovine beta-casein $5^{\prime}$ sequences in stably transfected mouse mammary cells. PNAS 87 9118-9122. 
Semba RD \& Neville MC 1999 Breast-feeding, mastitis, and HIV transmission: nutritional implication. Nutrition Reviews 75 146-153.

Shuster DE, Kehrli ME Jr \& Stevens MG 1993 Cytokine production during endotoxin-induced mastitis in lactating dairy cows. American Journal of Veterinary Research 54 80-85.

Shuster DE, Kehrli ME Jr, Rainard P \& Paape M 1997 Complement fragment $\mathrm{C} 5 \mathrm{a}$ and inflammatory cytokines in neutrophil recruitment during intramammary infection with Escherichia coli. Infection and Immunity 65 3286-3292.

Sibley CH, Terry A \& Raetz CRH 1988 Induction of K light chain synthesis in 70Z/3 B lymphoma cells by chemically defined lipid A precursors. Journal of Biological Chemistry 263 5098-5103.

SPSS 2002 SPSS for Windows, release 11.5. Chicago, IL: SPSS Inc.

Strange R, Li F, Saurer S, Burkhardt A \& Friis RR 1992 Apoptotic cell death and tissue remodeling during mouse mammary gland involution. Development 115 49-58.

Sympson CJ, Talhouk RS, Alexander CM, Chin JR, Clift SM, Bissell MJ \& Werb Z 1994 Targeted expression of stromelysin-1 in mammary gland provides evidence for a role of proteinases in branching morphogenesis and the requirement for an intact basement membrane for tissue-specific gene expression. Journal of Cell Biology 125 681-693.

Tak PP \& Firestein GS 2001 NF-кB: a key role in inflammatory diseases. Journal of Clinical Investigation 107 7-11.

Talhouk RS, Chin JR, Unemori EN, Werb Z \& Bissell MJ 1991 Proteinases of the mammary gland: developmental regulation in vivo and vectorial secretion in culture. Development 112 439-449.

Talhouk RS, Bissell MJ \& Werb Z 1992 Coordinated expression of ECM-degrading proteinases and their inhibitors regulate mammary epithelial function during involution. Journal of Cell Biology 118 $1271-1282$.

Talhouk RS, Hajjar L, Abou-Gergi R, Simaa'n CJ, Mouneimne G, Saade' NE \& Safieh-Garabedian B 2000a Functional interplay between gelatinases and hyperalesia in endotoxin-induced localized inflammatory pain. Pain 84 397-405.

Talhouk R, Mouneimne G, Beirouty M \& Safieh-Garabedian B 2000 b The effect of endotoxin on functional and morphological parameters of mammary CID-9 cells. Sixth International Endotoxin Society Meeting, Pasteur Institute, Paris, France, 24-27 August. Journal of Endotoxin Research 6 124a.

Talhouk R, Maa'ni F, Kalaa'ni N, Zoubian GS, Simaa'n CJ, Abi-Sai'd M, Hamadeh SK, Barbour E \& El-Sabban M 2001 Partial purification and characterization of growth factors involved in ovine mammary development. Domestic Animal Endocrinology 3 $143-159$.
Tarraf C, El-Sabban M, Bassam R, Beyrouthy M, Chamoun J \& Talhouk R 2003 Functional consequence of exposure to dieldrin on mammary development and function. Food Additives and Contaminants 20 819-828.

Tomita N, Morishita R, Tomita S, Gibbons GH, Zhang L, Horiuchi M, Kaneda Y, Higaki J, Ogihara T \& Dzau VJ 2000 Transcription factor decoy for NFkappaB inhibits cytokine and adhesion molecule expressions in synovial cells derived from rheumatoid arthritis. Rheumatology 39 749-757.

Von Andrian UH, Chambers JD, McEvoy LM, Bargatze RF, Arfors KE \& Butcher EC 1991 Two-step model of leukocyte-endothelial cell interaction in inflammation: distinct roles for LECAM- 1 and the leukocyte beta 2 integrins in vivo. PNAS 88 $7538-7542$.

Waller KP 2000 Mammary gland immunology around parturition. In Biology of the Mammary Gland. Advances in Experimental Medicine and Biology, 480, pp 231-245. Eds JA Mol \& RA Clegg. New York: Kluwer Academic/Plenum Publishers.

Wille JJ, Park J \& Elgavish A 1992 Effect of growth factors, hormones, bacterial lipopolysaccharide, and lipotechoic acids on the clonal growth of normal uretal epithelial cells in serum-free culture. Journal of Cellular Physiology 150 52-58.

Yang J, Kennelly JJ \& Baracos VE 2000 The activity of transcription factor Stat5 responds to prolactin, growth hormone, and IGF-I in rat and bovine mammary explant culture. Journal of Animal Science 78 3114-3125.

Yao PM, Maitre B, Delclaux C, Buhler JM, Harf A \& Lafuma C 1997 Divergent regulation of $92-\mathrm{kDa}$ gelatinase and TIMP-1 by HBECs in response to IL-1beta and TNF-alpha. American Journal of Physiology 273 L866-L874.

Yokoo T \& Kitamura M 1996 Dual regulation of IL-1 beta-mediated MMP9 expression in mesangial cell by NF-kappa B and AP-1. American Journal of Physiology 270 F123-F130.

Zhang Y, McCluskey K, Fujii K \& Wahl LM 1998 Differential regulation of monocyte matrix metalloprotease and TIMP-1 production by TNF- $\alpha$, granulocyte-macrophage CSF, and IL-1 $\beta$ through prostaglandin-dependent and independent mechanisms. Journal of Immunology $1613071-3076$.

Received 22 August 2003

First decision 30 October 2003

Revised manuscript received 3 December 2003

Accepted 2 January 2004 